\title{
PIVAL, AN ANTI-COAGULANT RODENTICIDE
}

\author{
By E. W. BENTLEY AND MARIAN ROWE \\ Infestation Control Division, Ministry of Agriculture, Fisheries and Food, \\ Tolworth, Surbiton, Surrey
}

\section{INTRODUCTION}

During the last few years the advent first of dicoumarin and then of its derivative warfarin [3-(1-phenyl-2-acetylethyl)-4-hydroxycoumarin)] has led to a rapid reduction in the use of quicker acting poisons such as zinc phosphide and arsenious oxide for rat control. The toxicity of warfarin is due, at least in part, to its depressing effect on the prothrombin level of the blood, which in turn leads to uncontrollable bleeding. The advantage of anti-coagulants lies in that, as far as is known, if they cause pain it is only after ingestion of several doses at the concentration usually employed. Thus, association of illness with food is avoided: so much so that rats may continue feeding long after a lethal dose has been eaten. A second advantage that follows from the spreading of the poisoning period over several days is that other animals are less likely to be harmed.

Since warfarin has been developed many other anti-coagulants have been examined as possible rodenticides. Chief among the requirements of such poisons are, perhaps, toxicity to mice and the common species of rat (in Britain and the U.S.A., Rattus rattus and $R$. norvegicus), absence of markedly greater toxicity to man, domestic animals and stock, palatability at the lowest concentration that causes complete mortality in a reasonable period, and cheapness. Of lesser importance are the speed with which the poison becomes effective and any fungicidal and insecticidal properties it may possess. Moulding of baits is a factor to be considered in most countries but baits are less frequently attacked by insects in Britain than where higher summer temperatures occur.

One anti-coagulant which has claimed attention is the compound 2-pivalyl-1,3indandione, marketed under the name of 'Pival'. It was first synthesized by Kilgore, Ford \& Wolfe (1942) and was further developed by the Wildlife Research Laboratory of the U.S. Fish and Wildlife Service at Denver, in conjunction with the owners of the patent - as described by Crabtree \& Robinson (1953). The latter authors gave an account of extensive field trials, in which 99-100\% successes were reported. Important insecticidal and fungicidal properties were also claimed. Apart from semi-confidential reports no information seems to be available on the comparative efficiency of Pival and other anti-coagulants such as warfarin and coumachlor. The present paper sets out the results of a preliminary laboratory investigation of Pival from this aspect. 


\section{METHODS}

The Pival* was in the form of a $0.5 \%$ concentrate in corn starch which is said to be palatable to rats. In all the tests to be described the poison was used at $0.025 \%$ by diluting the concentrate $1 / 20$ with a suitable bait. In the palatability and toxicity tests this was a medium grade oatmeal, which is frequently used with other anti-coagulant poisons in Britain.

Two methods were employed to assess very roughly the fungicidal action of Pival in rat baits. In the first the baits were exposed to very high humidity. Several Petri dishes containing different baits were placed either singly or together in desiccators over water and were examined daily for the appearance of moulds. In the second series of tests the various baits were placed in agricultural drainpipes, blocked at one end, and laid on the ground in the open air. The conditions of exposure were thus much as they would be during an outdoor rat control treatment.

In the toxicity tests the rats were caged singly and fed on the poison bait ad lib., either until they died, or for a limited number of days. The food pots were weighed daily and replenished.

The palatability tests were conducted as described elsewhere (Bentley, Hammond \& Taylor, 1955), and were normally continued for 4 nights only.

The rats were all wild. The $R$. norvegicus were caught by hand at a refuse destructor in the Midlands, and some had been kept in the laboratory for as long as 2 months before the tests. The $R$. rattus were obtained from a site in London and some of them had been kept in the laboratory for as long as $\mathbf{9}$ months. Since capture both species had been fed on a cubed diet.

\section{RESULTS}

\section{(a) Toxicity to Rattus norvegicus}

To compare the toxicity of Pival and warfarin to $R$. norvegicus two groups of twelve rats were fed on Pival at $0.025 \%$ for 2 and 3 days respectively. In the shorter test one rat died after 5 days. This was a male weighing $167 \mathrm{~g}$., and the amount of Pival it ate corresponded to a dosage of $48 \mathrm{mg}$. per $\mathrm{kg}$. of body weight. The other eleven rats survived dosages of $26-58 \mathrm{mg} . / \mathrm{kg}$. In the 3-day test six out of twelve rats died. One of the six was pregnant and, not surprisingly, died in 2 days, having eaten only $9 \mathrm{mg} . / \mathrm{kg}$. The other five ate the equivalent of 29,43 , 52,60 and $76 \mathrm{mg}$. of Pival $/ \mathrm{kg}$. of body weight. Since, however, the survivors withstood dosages of $18,44,56,65,71$ and $76 \mathrm{mg}$. $/ \mathrm{kg}$., considerable variation in susceptibility of the rats is indicated. Neither in the 2-day nor the 3-day test was there any obvious difference between males and females in their resistance to the poison.

In Table 1 the above results are summarized and compared with similarly obtained figures for warfarin (Bentley et al. 1955). On this showing Pival at $0.025 \%$, when ingested over 3 days, is rather less effective against $R$. norvegicus than warfarin at $0.005 \%$ (the dosage usually used for control of this species).

* Supplied by Motomco Ltd., New York, N.Y. 
Table 1. Comparative toxicity of Pival and warfarin to Rattus norvegicus

\begin{tabular}{|c|c|c|c|c|c|c|c|}
\hline Poison & $\begin{array}{c}\text { Strength } \\
(\%)\end{array}$ & $\begin{array}{l}\text { No. of } \\
\text { days in } \\
\text { test }\end{array}$ & Mortality & $\begin{array}{l}\text { Dosage } \\
\text { range that } \\
\text { killed } \\
\text { (mg./kg.) }\end{array}$ & $\begin{array}{l}\text { Dosage } \\
\text { range that } \\
\text { failed } \\
\text { to kill }\end{array}$ & $\begin{array}{l}\text { Average } \\
\text { no. days } \\
\text { to death }\end{array}$ & $\begin{array}{c}\text { Range of } \\
\text { days to } \\
\text { death }\end{array}$ \\
\hline Pival & 0.025 & 2 & $1 / 12$ & 48 & $25-58$ & 5 & 一 \\
\hline Pival & 0.025 & 3 & $6 / 12^{*}$ & $29-76$ & $18-71$ & $4 \cdot 2$ & 4-6 \\
\hline Warfarin & 0.005 & 1 & $5 / 12$ & $3 \cdot 1-4 \cdot 5$ & $2-4.5$ & $6 \cdot 2$ & $5-9$ \\
\hline Warfarin & 0.005 & 2 & $15 / 23$ & $5 \cdot 2-9 \cdot 9$ & $5 \cdot 5-11 \cdot 5$ & $6 \cdot 6$ & $4-10$ \\
\hline Warfarin & 0.005 & 3 & $12 / 12$ & $6 \cdot 2-12 \cdot 3$ & - & $6 \cdot 2$ & $4-7$ \\
\hline
\end{tabular}

(b) Palatability to Rattus norvegicus

The results of offering a choice of $0.025 \%$ Pival and $0.025 \%$ warfarin to a total of thirty-five $R$. norvegicus for 2 days are given in Table 2. The 4-day totals were similar but are not quoted since by the third day some of the animals were sickening and therefore eating less. Only eight rats preferred the bait containing Pival, and the significance of the overall preference for warfarin is clear (Student's ' $t$ ' test applied to the data gives a probability of about 0.001 ).

\section{(c) Toxicity to Rattus rattus}

Information regarding the toxicity of Pival to $R$. rattus was obtained by feeding ship rats on poisoned bait for 5 days and 7 days (Table 3 ).

In the 5-day test three out of eleven animals died. Death occurred after 7, 9 and 10 days at dosages of 101,84 and $96 \mathrm{mg}$. $/ \mathrm{kg}$. respectively. Only one of the remaining eight rats showed signs of illness and this animal survived the equivalent of $166 \mathrm{mg} . / \mathrm{kg}$. over the 5 days. Six rats survived dosages of $105 \mathrm{mg}$. or more per kg.

In the 7-day tests eleven out of twelve rats died in periods varying from 4 to 13 days. The lethal dosages ranged from 23 to $135 \mathrm{mg}$. $/ \mathrm{kg}$. (mean dosage

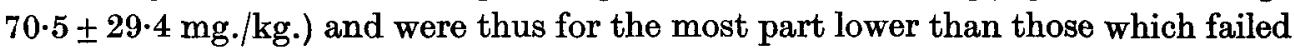
to kill in the 5-day test. For no obvious reason the rats in the 7-day test ate rather less per day than the animals fed on Pival for 5 days, and since only five of them were eating appreciable amounts of food by the seventh day, the greater mortality could not have been due wholly to the extra 2 days. It is suggested that young ship rats are perhaps less susceptible to Pival than heavier animals since the mean weight of the animals fed on Pival for 7 days was $164 \pm 34 \mathrm{~g}$., while that of the rats used in the 5-day test was only $111 \pm 22 \cdot 6 \mathrm{~g}$.

The possibility of a weight effect is supported by data obtained by feeding thirtysix $R$. rattus on $0.025 \%$ Pival until they died. The weights of the rats varied from 99 to $247 \mathrm{~g}$. and the dosages of Pival ingested varied between 34 and $165 \mathrm{mg} . / \mathrm{kg}$. (mean dosage $96.6 \pm 33.9 \mathrm{mg} . / \mathrm{kg}$.). The co-efficient of correlation between weight and dosage was -0.486 , for which $P=0.01$ approximately. Since, from the nature of the assay, any of the animals may have ingested much more than a lethal dose, it is possible that the correlation observed here was not because the heavier 
animals succumbed to a lower dosage but because the poison affected their feeding earlier than in the case of the lighter rats: for there was no significant correlation between weight and survival time (4-21 days; mean 9.7 $\pm 2 \cdot 7$ days). Against this, however, most of the animals were feeding to some extent until $24 \mathrm{hr}$. before death.

Table 2. Comparative acceptance of $0.025 \%$ Pival and $0.025 \%$ warfarin by Rattus norvegicus

\begin{tabular}{|c|c|c|c|c|c|}
\hline Rat no. & Sex & $\begin{array}{l}\text { Weight } \\
\text { (g.) }\end{array}$ & $\begin{array}{l}\text { Pival bait } \\
\text { eaten in } \\
2 \text { days } \\
\text { (g.) }\end{array}$ & $\begin{array}{l}\text { Warfarin bait } \\
\text { eaten in } \\
2 \text { days } \\
\text { (g.) }\end{array}$ & $\begin{array}{c}\text { Difference } \\
\text { (g.) }\end{array}$ \\
\hline A465 & F. & 303 & $25 \cdot 2$ & 3.9 & $-21 \cdot 3$ \\
\hline A 466 & F. & 255 & $19 \cdot 7$ & 14.8 & -4.9 \\
\hline A504 & F. & 415 & $10 \cdot 2$ & $31 \cdot 7$ & $21 \cdot 5$ \\
\hline A 505 & M. & 270 & $13 \cdot 9$ & $15 \cdot 5$ & $1 \cdot 6$ \\
\hline A512 & M. & 298 & $25 \cdot 8$ & $20 \cdot 3$ & $-5 \cdot 5$ \\
\hline A 537 & F. & 348 & $21 \cdot 8$ & $25 \cdot I$ & $3 \cdot 3$ \\
\hline A 538 & M. & 317 & $4 \cdot 2$ & $40 \cdot 0$ & $35 \cdot 8$ \\
\hline A 539 & F. & 356 & $18 \cdot 6$ & $25 \cdot 7$ & $7 \cdot 1$ \\
\hline A 540 & M. & 342 & $18 \cdot 5$ & $35 \cdot 6$ & $17 \cdot 1$ \\
\hline A 549 & M. & 360 & $30 \cdot 2$ & $22 \cdot 4$ & $-7 \cdot 8$ \\
\hline A 550 & F. & 208 & $22 \cdot 9$ & $20 \cdot 0$ & $-2 \cdot 9$ \\
\hline В 109 & F. & 177 & $5 \cdot 9$ & $12 \cdot 7$ & $6 \cdot 8$ \\
\hline B 123 & F. & 162 & $8 \cdot 2$ & $10 \cdot 5$ & $2 \cdot 3$ \\
\hline В 124 & M. & 181 & $1 \cdot 9$ & $20 \cdot 3$ & $18 \cdot 4$ \\
\hline B 131 & F. & 130 & $5 \cdot 6$ & $7 \cdot 9$ & $2 \cdot 3$ \\
\hline B 132 & M. & 171 & $5 \cdot 1$ & $12 \cdot 8$ & $7 \cdot 7$ \\
\hline В 133 & M. & 171 & $3 \cdot 4$ & $18 \cdot 8$ & $15 \cdot 5$ \\
\hline B 134 & M. & 184 & $1 \cdot 6$ & $14 \cdot 5$ & $12 \cdot 9$ \\
\hline B 135 & F. & 117 & $0 \cdot 0$ & $17 \cdot 1$ & $17 \cdot 1$ \\
\hline B 136 & F. & 155 & $3 \cdot 8$ & $18 \cdot 5$ & $14 \cdot 7$ \\
\hline B 137 & F. & 123 & $2 \cdot 3$ & $15 \cdot 6$ & $13 \cdot 3$ \\
\hline B 145 & F. & 129 & $3 \cdot 8$ & $14 \cdot 7$ & $10 \cdot 9$ \\
\hline B 146 & F. & 140 & $5 \cdot 5$ & $14 \cdot 2$ & $8 \cdot 7$ \\
\hline B 110 & F. & 159 & $4 \cdot 2$ & $15 \cdot 1$ & $10 \cdot 9$ \\
\hline B 112 & F. & 176 & 0.2 & $15 \cdot 2$ & $15 \cdot 0$ \\
\hline B 141 & F. & 157 & $4 \cdot 4$ & $18 \cdot 9$ & 14.5 \\
\hline B 160 & F. & 298 & $20 \cdot 4$ & $13 \cdot 8$ & $-6 \cdot 6$ \\
\hline B 163 & M. & 310 & $7 \cdot 8$ & $30 \cdot 3$ & $22 \cdot 5$ \\
\hline B 164 & M. & 215 & $17 \cdot 5$ & $12 \cdot 9$ & $-4 \cdot 6$ \\
\hline B 165 & M. & 334 & $5 \cdot 5$ & $23 \cdot 5$ & $18 \cdot 0$ \\
\hline В 166 & F. & 230 & $6 \cdot 9$ & $27 \cdot 4$ & $20 \cdot 5$ \\
\hline В 247 & M. & 253 & 0.1 & $28 \cdot 2$ & $28 \cdot 1$ \\
\hline B 248 & F. & 173 & $1 \cdot 4$ & $23 \cdot 2$ & $21 \cdot 8$ \\
\hline B 249 & M. & 302 & $10 \cdot 3$ & $22 \cdot 0$ & $11 \cdot 7$ \\
\hline B 250 & M. & 331 & $36 \cdot 0$ & $1 \cdot 4$ & $-34 \cdot 6$ \\
\hline Total & - & - & $372 \cdot 8$ & $664 \cdot 6$ & 291.8 \\
\hline
\end{tabular}

In Table 3 the results of the 5- and 7-day tests are compared with those from similar assays using warfarin at $0.025 \%$, the usually recommended dosage for the control of $R$. rattus. In both cases slightly better results were obtained with Pival. However, for an unknown reason the rats which were fed on the latter ate more bait than in the test with warfarin. In the 5-day experiment with Pival one rat 
showed some bleeding but recovered. Several rats fed on warfarin for the same period also became ill but survived.

The results of the test mentioned above in which thirty-six $R$. rattus were fed on Pival until death may be compared with the figures from a trial in which twentyfour ship rats were given $0.025 \%$ warfarin under the same conditions. The weights

Table 3. Comparative toxicity of $0.025 \%$ Pival and $0.025 \%$ warfarin to Rattus rattus

$\begin{array}{lcccccc}\text { No. of } & \begin{array}{c}\text { Dosage } \\ \text { days of } \\ \text { test }\end{array} & \text { Mortality } & \begin{array}{c}\text { Dosage } \\ \text { range that } \\ \text { killed } \\ (\mathbf{m g} . / \mathrm{kg} \text {.) }\end{array} & \begin{array}{c}\text { range that } \\ \text { failed to } \\ \text { kill }\end{array} & \begin{array}{c}\text { Average } \\ \text { no. of } \\ \text { days to } \\ \text { death }\end{array} & \begin{array}{c}\text { Range of } \\ \text { time to } \\ \text { death }\end{array} \\ \text { Pival } & 5 & 3 / 11 & 84-101 & 65-166 & 8 \cdot 7 & 7-10 \text { days } \\ \text { Pival } & 7 & 11 / 12 & 23-135 & 71 & 8 \cdot 5 & 4-13 \text { days } \\ \text { Warfarin } & 5 & 1 / 12 & 105 & 32-76 & - & 8 \text { days } \\ \text { Warfarin } & 7 & 10 / 12 & 33-110 & 112-113 & 8 \cdot 8 & 5-12 \text { days }\end{array}$

Table 4. Acceptance by Rattus rattus of plain oatmeal and oatmeal containing $0.025 \%$ Pival during 4 days

\begin{tabular}{|c|c|c|c|c|c|}
\hline Rat no. & Sex & $\begin{array}{l}\text { Weight } \\
\text { (g.) }\end{array}$ & $\begin{array}{l}\text { Plain } \\
\text { oatmeal eaten } \\
\text { (g.) }\end{array}$ & $\begin{array}{l}\text { Pival bait } \\
\text { eaten } \\
\text { (g.) }\end{array}$ & $\begin{array}{c}\text { Difference } \\
\text { (g.) }\end{array}$ \\
\hline A 263 & M. & 160 & $34 \cdot 8$ & $4 \cdot 9$ & $29 \cdot 9$ \\
\hline A 264 & M. & 151 & $20 \cdot 5$ & $9 \cdot 4$ & $11 \cdot 1$ \\
\hline A 265 & M. & 202 & $13 \cdot 8$ & $28 \cdot 2$ & $-14 \cdot 4$ \\
\hline A 266 & F. & 99 & $20 \cdot 8$ & $2 \cdot 8$ & $18 \cdot 0$ \\
\hline A 269 & M. & 188 & $23 \cdot 2$ & $19 \cdot 5$ & $3 \cdot 7$ \\
\hline A 270 & F. & 151 & $36 \cdot 3$ & $7 \cdot 6$ & $28 \cdot 7$ \\
\hline A 278 & F. & 124 & $17 \cdot 4$ & $12 \cdot 5$ & $4 \cdot 9$ \\
\hline A 279 & M. & 140 & $27 \cdot 9$ & 0.4 & $27 \cdot 5$ \\
\hline A 280 & F. & 174 & $26 \cdot 2$ & $14 \cdot 5$ & $11 \cdot 7$ \\
\hline A 281 & M. & 165 & $23 \cdot 9$ & 24.5 & -0.6 \\
\hline A 283 & F. & 159 & $27 \cdot 4$ & $8 \cdot 8$ & $18 \cdot 6$ \\
\hline A 284 & F. & 99 & $12 \cdot 3$ & $14 \cdot 0$ & -1.7 \\
\hline Totals & - & - & $284 \cdot 5$ & $147 \cdot 1$ & $137 \cdot 4$ \\
\hline
\end{tabular}

of the animals were of the same order $(92-212 \mathrm{~g}$.) and the dosages ingested varied between 34 and $216 \mathrm{mg} . / \mathrm{kg}$. (mean $102 \pm 53 \mathrm{mg} . / \mathrm{kg}$.). The time until death $(10 \cdot 4 \pm 2 \cdot 5$ days $)$ was slightly but not significantly longer than in the case of the rats fed on Pival. Once more examination of the figures shows a significant negative correlation ( $-0.48, P=0.02)$ between weight of rat and dosage. There were also vague indications that female rats were more resistant than males. Here again, however, since all or any of the rats may have eaten more than a lethal dose and almost all were feeding a little within $24 \mathrm{hr}$. of death it is difficult to interpret this result without more data.

\section{(d) Palatability to Rattus rattus}

Table 4 shows the results of the first 4 days of a longer test in which twelve ship rats were offered a choice of plain oatmeal and oatmeal containing $0.025 \%$ Pival. During these 4 days there was no sign of diminished feeding. Only one rat ate 
much more of the Pival than of the plain bait. The latter was clearly preferred $(P=0 \cdot 02)$.

The data from two similar 4-day tests in which a total of twenty-two rats were presented with a choice of Pival and warfarin, both at $0.025 \%$, are given in Table 5. The total difference in consumption was small $(P=0 \cdot 3-0 \cdot 4)$, and it may be inferred that the two poisons are about equally acceptable at the concentration used.

Table 5. Comparative acceptance of $0.025 \%$ warfarin and $0.025 \%$ Pival by Rattus rattus during 4 days

\begin{tabular}{|c|c|c|c|c|c|}
\hline Rat no. & Sex & $\begin{array}{c}\text { Weight } \\
\text { (g.) }\end{array}$ & $\begin{array}{l}\text { Warfarin } \\
\text { eaten } \\
\text { (g.) }\end{array}$ & $\begin{array}{c}\text { Pival } \\
\text { eaten } \\
\text { (g.) }\end{array}$ & $\begin{array}{c}\text { Difference } \\
\text { (g.) }\end{array}$ \\
\hline A 198 & M. & 198 & $15 \cdot 7$ & $24 \cdot 0$ & $8 \cdot 3$ \\
\hline A 271 & F. & 108 & $30 \cdot 2$ & $11 \cdot 5$ & $18 \cdot 7$ \\
\hline A 272 & F. & 93 & $22 \cdot 9$ & $17 \cdot 1$ & $5 \cdot 8$ \\
\hline A 273 & M. & 187 & $21 \cdot 5$ & $21 \cdot 5$ & $0 \cdot 0$ \\
\hline A 274 & M. & 201 & $15 \cdot 2$ & $29 \cdot 1$ & $-13 \cdot 9$ \\
\hline A 285 & F. & 186 & $14 \cdot 8$ & 27.8 & -13.0 \\
\hline A 286 & F. & 165 & $19 \cdot 6$ & $15 \cdot 9$ & $3 \cdot 7$ \\
\hline A 287 & M. & 180 & $18 \cdot 8$ & $40 \cdot 9$ & $-22 \cdot 1$ \\
\hline A 288 & F. & 162 & $28 \cdot 7$ & $24 \cdot 5$ & $4 \cdot 2$ \\
\hline A 289 & F. & 194 & $36 \cdot 8$ & $11 \cdot 2$ & $25 \cdot 6$ \\
\hline A 297 & M. & 133 & $28 \cdot 4$ & $23 \cdot 3$ & $5 \cdot 1$ \\
\hline A 308 & F. & 99 & $21 \cdot 6$ & $15 \cdot 6$ & $6 \cdot 0$ \\
\hline A 796 & F. & 135 & $13 \cdot 9$ & $15 \cdot 9$ & $-2 \cdot 0$ \\
\hline A 819 & M. & 168 & $6 \cdot 7$ & $5 \cdot 9$ & 0.8 \\
\hline A 820 & M. & 226 & $20 \cdot 5$ & $15 \cdot 7$ & $4 \cdot 8$ \\
\hline A 821 & M. & 211 & $13 \cdot 8$ & $9 \cdot 4$ & $4 \cdot 4$ \\
\hline A 822 & F. & 172 & $17 \cdot 3$ & $18 \cdot 3$ & $-1 \cdot 0$ \\
\hline A 823 & F. & 147 & $15 \cdot 4$ & $15 \cdot 8$ & $-0 \cdot 4$ \\
\hline A 832 & F. & 145 & $17 \cdot 5$ & $20 \cdot 5$ & $-3 \cdot 0$ \\
\hline A 841 & F. & 111 & $13 \cdot 7$ & $10 \cdot 2$ & $3 \cdot 5$ \\
\hline A 903 & F. & 115 & $27 \cdot 6$ & $10 \cdot 0$ & $17 \cdot 6$ \\
\hline A 967 & M. & 179 & $24 \cdot 7$ & $14 \cdot 4$ & $10 \cdot 3$ \\
\hline Total & - & - & $445 \cdot 3$ & 398.5 & $46 \cdot 8$ \\
\hline
\end{tabular}

\section{(e) Fungicidal properties}

In one series of moulding tests damp baits consisting of coarse oatmeal plus $35 \%$ by weight of water, with and without Pival, were used. In all dishes moulds first appeared on the fourth day. On the plain bait the mould colonies spread rapidly and produced sporangia, whereas on the baits containing Pival the colonies spread very slowly and remained patchy. This test was then repeated with the two baits in separate vessels to prevent any cross-infection; both baits then became visibly mouldy on the third day. As before the mould spread rapidly on the plain bait but remained as small colonies on the Pival bait.

In a second series of moulding tests dry medium oatmeal with and without Pival was used. In this instance both baits became visibly mouldy after 11 days. The mould colonies spread only slowly and no visible difference was found between their extent on the bait with Pival and that without. 
In the drain-pipe tests the same baits were used as in the 'desiccator' tests, namely, damp, coarse oatmeal with and without Pival; and dry, medium oatmeal with and without Pival. It was found that the damp baits both with and without Pival, and the dry oatmeal without Pival, became visibly mouldy after 11 days. The dry medium oatmeal with added Pival became mouldy after 14 days.

\section{DISCUSSION AND CONCLUSIONS}

The moulding tests described in the preceding paragraphs, though rough, are sufficient to indicate that the fungicidal properties of Pival are not very marked. We are indebted to Dr E. J. Miller for the observation that the flour-beetle Tribolium castaneum will breed in $0.025 \%$ Pival baits but not as rapidly as in the untreated bait-base.

The results above show that Pival at $0.025 \%$ is less toxic than warfarin at $0.005 \%$ to Rattus norvegicus when eaten over periods up to $72 \mathrm{hr}$. Moreover it appears to be somewhat less palatable than warfarin to the common rat.

The figures for the toxicity of $0.025 \%$ Pival and warfarin to $R$. rattus suggest that the former is slightly more effective but the difference, if real, is unlikely to be of practical importance. The choice tests indicate that $R$. rattus can taste or otherwise detect Pival in a simple cereal bait and, as in the case of warfarin, finds it somewhat unpalatable: also that both poisons appear to be about equally acceptable. Since warfarin is, nevertheless, taken readily by ship rats when attractive baits are used, it may be assumed that $R$. rattus could be induced without difficulty to feed also on baits containing $0.025 \%$ Pival.

There is little information at present on the toxicity of Pival to other animals. Beauregard, Tusing \& Hanzal (1955) report an acute lethal dose of the order of $75-100 \mathrm{mg} . / \mathrm{kg}$. of body weight in dogs. To obtain $100 \mathrm{mg}$. $/ \mathrm{kg}$. from a bait containing $0.025 \%$ Pival, a dog would need to eat two-fifths of its body weight. The same authors found that Pival was fatal to dogs at about $15-35 \mathrm{mg} . \mathrm{kg}$. if administered in daily doses of $2.5 \mathrm{mg}$. $/ \mathrm{kg}$. In limited observation on cats they noticed no effects when the animals were given the equivalent of one Pivalpoisoned mouse per day for 13 days or two poisoned mice for 2 days.

Exactly comparable data for warfarin do not seem to be available but there is nothing here to suggest that the substitution of Pival for warfarin would involve greater hazards.

Thus, from the stand-points of toxicity and palatability, laboratory tests suggest that Pival would be a suitable alternative to warfarin against Rattus rattus and that against $R$. norvegicus warfarin is to be preferred.

It is true that Pival could be used at some concentration greater than $0.025 \%$ at which it would be as lethal to $R$. norvegicus as warfarin is at $0.005 \%$ or $0.025 \%$. This, however, would probably make it more unpalatable (and thus necessitate the use of masking agents), add to the risk of killing other animals, and increase the cost of control treatments. 


\section{SUMMARY}

1. Pival at $0.025 \%$ is somewhat less toxic than warfarin at $0.005 \%$ to $R$. norvegicus when ingested for periods up to $72 \mathrm{hr}$. It is also less acceptable in a dry cereal bait.

2. Pival and warfarin at $0.025 \%$ are about equally toxic and equally acceptable to $R$. rattus.

3. Young $R$. rattus appear to be more resistant than heavier rats to both Pival and warfarin.

4. The fungicidal properties of Pival are discussed.

\section{REFERENCES}

Beauregard, J. R., Tusing, T. W. \& Hanzal, R. F. (1955). Toxicity and antidotal studies on 2-pivalyl-1,3-indandione (Pival), an anti-coagulant rodenticide. J. Agric. Fid Chem. 3, 124-7.

Bentley, E. W., Hammond, L. E. \& Taylor, E. J. (1955). The comparative toxicity of $0.025 \%$ and $0.005 \%$ warfarin to Rattus norvegicus. Plant Pathology, 4, 120-3.

Crabtree, D. G. \& Robinson, W. H. (1953). Pivalyl, the new insecticidal rodenticide. Pest Control, July 1953, pp. 22, 24, 58.

KILgore, L. B., Ford, J. H. \& WolfE, W. C. (1942). Insecticidal properties of 1,3-indandiones. Industr. Engng Chem. 34, 494-7.

(MS. received for publication 19. VII. 55) 